\title{
INCLUSIVE APPROACH FOR QUALITY AND SAFETY ENVIRONMENT IMPROVEMENT IN OIL AND GAS INDUSTRY
}

\author{
Mochammad Wahyu Ghani ${ }^{1}$ and Marya Yenita Sitohang ${ }^{2}$ \\ Research Center for Population, \\ Indonesian Institute of Sciences (LIPI), Jakarta, Indonesia ${ }^{1,2}$ \\ Corresponding Author Email: wayghani@gmail.com ${ }^{I}$
}

\begin{abstract}
Implementing safety behavior in the oil and gas industries is still challenging, although fatal accidents often occur. This research aims to analyze how Safety Health Environment Quality (SHEQ) talks, a Badak LNG program, can successfully prevent workers' work accidents. Using qualitative methods with a case study approach, the researchers interviewed several key persons in the SHEQ talk program, including the board of management, the SHEQ department's employees, and Badak LNG's employers. Inclusiveness is the main component in the SHEQ talks program. It leads to safety behavior among all Badak LNG's workers (interdependent stage). Unlike the usual behavior-based safety program, SHEQ talks encourage all employees to have good knowledge and skill of health and safety environments. Therefore, safety performance among the workers does not entirely depend on the Occupational safety and health $(\mathrm{OSH})$ officers. Eliminating the superior and subordinate when conducting the safety talks are essential to build the safety culture among workers in the oil and gas industries.
\end{abstract}

Keywords: Badak LNG, communication, safety behaviour, SHEQ talks

\section{ABSTRAK}

Mewujudkan kesehatan dan keselamatan kerja di industri minyak dan gas masih menjadi tantangan karena banyak kecelakaan fatal terjadi di industri ini. Penelitian ini bertujuan untuk menganalisis bagaimana program Safety Health Environment Quality (SHEQ) talk oleh Badak LNG berhasil mencegah terjadinya kecelakaan kerja di lingkungan industri. Menggunakan metode kualitatif dengan pendekatan studi kasus, peneliti mewawancarai beberapa informan kunci yaitu dalam manajer program SHEQ talks, karyawan departemen SHEQ (petugas $K_{3}$ ), dan pekerja Badak LNG. Inklusivitas dalam penerapan program SHEQ talks mendorong semua pekerja Badak LNG memiliki perilaku keselamatan kerja yang baik. Semua pekerja diharapkan mampu mengisi materi dalam program SHEQ talks sehingga mereka memiliki pengetahuan yang menyeluruh tentang kesehatan dan keselamatan kerja. Berbeda dari program safety perusahaan pada umumnya, SHEQ talk mendorong semua pekerja untuk bisa berperan menjadi petugas Kesehatan dan keselamatan kerja $\left(K_{3}\right)$ bagi diri mereka sendiri dan pekerja lain. Oleh karena itu, perilaku keselamatan kerja para pekerja tidak sepenuhnya bergantung pada petugas $K_{3}$. Menghilangkan batasan antara atasan dan bawahan saat mengkomunikasikan perilaku keselamatan kerja pada pekerja sangat penting dilakukan untuk mewujudkan budaya keselamatan kerja di kalangan pekerja industri minyak dan gas.

Kata kunci : Badak LNG, komunikasi, perilaku keselamatan kerja, SHEQ talks, 


\section{INTRODUCTION}

The oil and gas industry is a kind of workplace that is identical to fatal accidents (Theophilus et al., 20I7). ${ }^{\mathrm{I}}$ A fatal accident occurs when the accident makes the worker suffered serious injury for more than three weeks to die. In some cases, the failure production of oil and gas pipes leads to an adverse condition for the workers. From I99 8 to 20II, 4.329 workers worldwide experienced fatal accidents from 20 terrible oil and gas failure production (Biezma et al., 2020). Moreover, in 2015, Indonesia had I05.I82 work accidents in the oil and gas sector, making more than two thousand workers dead (Septalita, 20I8).

The oil and gas industry usually uses behavior safety-based (BBS) approaches to prevent fatal accidents (Galis et al., 20I8; Zigulis, 2015; Salam et al., 2013; Ismail et al., 20I2). BBS aims to understand and modify workers' behavior to improve safety and health performance (Galis et al., 2018; Salam et al., 2013). Human error on managerial and operation became the primary cause of several work accidents in the oil and gas industry (Theophilus et al., 20I7; Ismail et al., 20I2). ${ }^{2}$ According to ILO (International Labour Organization), the cause of work accidents can be divided into two, i.e., unsafe conditions and unsafe action. Among these two, unsafe action causes $80 \%$ of the work accidents. The low level of education, lack of safety training, lack of inspection at the workplace, and no seriousness in implementing preventive measures are some behavior that causes the work accident (Zhang et al., 20I6).

BBS is implemented in oil and gas companies by their own styles and called with different names such as STOP, ASA, SOC, and many more (Salam et al., 20I3). Furthermore,

I Decree of the Minister of Energy and Mineral Resources Number I827 K / 30 / MEM / 2018 concerning Guidelines for Implementing Good Mining Engineering Principles. Attachment III letter A number I letter b.

2 Lestari, Fatma, 2014, Strategi Peningkatan Keselamatan Kerja \& Keselamatan Publik di Indonesia melalui Pendekatan Sistematik Pencegahan Kecelakaan. http:// uiupdate.ui.ac.id/content/strategi-peningkatan-keselamatan-kerja-keselamatan-publik-di-indonesia-melaluipendekatan. Accessed on 20 February 202009.00 WIB
Galis et al., (2018) identified seven challenges in implementing the BBS approach; data management barrier, superior understanding of BBS benefit, employees' attitudes toward change, top management awareness of BBS approach, company safety culture, internal conflict, and financial issues.

One of Indonesia's oil and gas industries that is already successful in applying the BBS approach is Badak Liquefied Natural Gas (LNG). As a world-class liquefied natural gas producer, Badak LNG has made a management system and procedure about health and safety environment called Safety Health Environment Quality Management System (SHEQ-MS). ${ }^{3}$ The impact of the SHEQ MS program is the zero work accident for many years. Even in 20I9, Badak LNG made a brilliant achievement through the accident in Ioo hours.

For continual sustainable improvement of safety in the workplace, the safety management systems must be supplemented by implementing safety culture improvement programs properly. Safety standards and work procedures should be analyzed as a part of the organization's communication, not just as a tool. Besides, the main principle of the BBS approach is that ownership of safety is given to the person at most risk (Salam et al., 20I3). BBS application quality is not a program, but an integrated management "process" (Ismail et al., 20I2). As part of the SHEQ MS program, SHEQ talks play a primary role in modifying the workers' behavior.

SHEQ talks serve as a bridge that minimizes misunderstandings of information about the SHEQ culture from unequal communication between classes of employees at Badak LNG. Executives and workers relate to the management system very differently, which affects communication (Wold \& Laumann, 2015). Distortions or misunderstandings arise from the lack of equivalence between the two sides in the communicative exchange. Therefore, this

3 Badak LNG. (20I9). safety, health and environment, innovative, professionalism, integrity \& dignity "Kisah di Balik roo Juta Jam Kerja Aman Resep Jitu di Balik Ioo Juta Jam Kerja Aman.” Badak LNG Magazine, 4Ist Edition. 
paper will focus on how the SHEQ program successfully communicates and builds the safety culture among Badak LNG workers.

\section{METHODS}

\section{Study Design}

This study applies a descriptive and exploratory qualitative research design to investigate social phenomena and human problems, in this case, the interaction between employees when facing HSE problems in a company environment. In this approach, researchers create elaborate descriptions, examine words, reporting detailed views of respondents, and conduct research in natural situations (Creswell, 20I4). The purpose of qualitative research is to seek and obtain in-depth information from much information. Bogdan and Taylor (Iskandar, 200I9) define a qualitative research methodology as a research procedure that produces descriptive data in written or spoken words from people and observable behavior.

The qualitative approach's descriptive nature enables researchers to construct complex and holistic pictures in natural settings (Creswell \& Poth, 20I7) and explore the beliefs, values, and motives that explain why certain behaviors occur (Castleberry \& Nolen, 2018). In-depth interviews and participant observation are used to gain in-depth knowledge of specific barriers and motivations in SHEQ culture behavior.

\section{Study Site and Participant}

This research was conducted in 2016 using direct participant observation and in-depth interviews of SHEQ Department employees and general employees in the Badak LNG environment. Badak LNG is located on the east coast of Kalimantan, precisely in Bontang City, South Bontang District, about I05 km northeast of Samarinda City. Participant observation provides an intuitive understanding of what is happening in culture and allows one to speak with confidence about the meaning of data; participant observation helps understand the meaning of the observation itself (Bernard, 2006). The method approach used in this research is an intrinsic case study. Case studies are conducted to understand better and deeper about a particular case. Studies or cases are carried out because researchers intend to understamd intrinsically a phenomenon, sequence, and specificity of a case, not for other external reasons (Herdiansyah, 20II). This research employed a single case study design with the research object, namely the employees of Badak LNG, totalling I2 people and spread over I2 departments.

\section{Data Collection and Analysis}

The research begins after obtaining approval from the company, in this case, the Corporate Communication Department. All in-depth interviews and observations were carried out directly in the Badak LNG company environment. Each interview took no more than an hour and was audio-recorded. Time varies based on the discussions between researchers and the saturation of information obtained from informants. Each session was audio-recorded and transcribed. After that, the researchers informed that the interview would be kept confidential and encouraged each employee to share all the knowledge one had about the SHEQ talks program and SHEQ culture.

After that, the audio files were transcribed word for word and then checked with each session's audio recording to ensure accuracy. Data analysis involved thematic analysis of transcripts based on the constructs of symbolic interaction theory. Thematic analysis is a method for identifying, analyzing, and reporting patterns (themes) in data. Thematic analysis of open responses from transcribed interviews can explore context while allowing flexibility and interpretation when analyzing data. However, it should be done with special attention and attention to the transparency of methods to ensure confidence in the findings (Castleberry \& Nolen, 20I8). The researchers first analyzed the transcripts separately and then reached a consensus on the identified themes and patterns. Content is analyzed both within and across focus groups. Then, the interpretation of the data will be presented in both the results and the discussion. 


\section{RESULTS}

SHEQ talks program uses formal and informal communications based on the summary guidelines for life-saving rules and the SHEQ's policy summary. The guidelines for the SHEQ Talks material come from a life-saving rules summary and a SHEQ's policy summary. The function of SHEQ talks itself is to remind the importance of preventing work accidents based on a summary of the life-saving rules and SHEQ's policies. With these guidelines, the SHEQ talk discussion will be adjusted and developed by each communicator according to current essential issues or never have arisen before.

“.....Sebenarnya kalau mau dibilang, SHEQ Talks itu berisi pesan-pesan SHEQ culture aga kurang tepat, bukan kurang tepat tapi kurang lengkap. Karena pesan-pesan atau informasi yang menjadi pedoman SHEQ Talks harus berlandaskan dengan ringkasan life saving rules dan ringkasan kebijakan SHEQS (Safety, Health, Environment, Quality and Security). Nah, tetapi secara garis besar tujuan life saving rules dan ringkasan kebijakan SHEQ itu juga untuk mensukseskan SHEQ culture juga." (Actually, it is not right to say SHEQ talks contain SHEQ message culture because SHEQ talks information has to be based on the life saving rules summary and SHEQ policy. Generally, the lifesaving rules summary and SHEQ policy aim to support the SHEQ culture.)

(In-depth interview with one of Badak LNG workers SHEQ Department)

Every oil and gas industry arranges its lifesaving rules, which summarize all components of the health and safety environment. Badak LNG divides the rules of health and safety environment into seven categories. First is a permit to work that must be obtained before starting a job. Secondly is the rule when working at height. If the height is more than 2 meters, workers must comply with the working at height requirements. Third, the isolation energy or Lock Out-Tag Out (LO-TO) is required for all work related to energy sources. Fourth, confined space entry leads to a need for permits and procedures when entering and working in confined spaces. Furthermore, there is a lifting operations aspect when workers must have a lifting plan while working with lifting equipment. Additionally, to fulfil the vehicle/ equipment safety, the driver must have a driver's license, and the vehicle has a good mark. Lastly, the excavation and ground disturbances aspect encourages workers to plan and identify excavation hazards.

Moreover, the SHEQS policies, which also guide SHEQ talks, contain six points, as explained below.

I. Prevention of accidents, fire/explosion, occupational diseases, environmental pollution, product quality failure, and poor service and safety problems.

2. Compliance with Laws and Regulations relevant to SHEQS.

3. Development and maintenance of a SHEQS culture and customer satisfaction.

4. Continuous improvement to the SHEQS Management System.

5. The realization of a harmonious relationship between workers and the surrounding community.

6. Safety is everyone's responsibility, and Environmental Management is directly responsible for preventing injuries, occupational diseases, environmental pollution, failure of product quality and poor service as well as security problems.

For the formal SHEQ talks, Badak LNG regulates SHEQ talks for each department according to the insight from SHEQ Committee Meetings at the beginning of each year. The primary purpose of SHEQ committee meetings is to create a work plan or target as well as the determination of SHEQ coordinators in each department in Badak LNG. One of the agenda is to arrange the SHEQ talks schedule for each employee. Every worker is required to take part as a speaker in the SHEQ talks every month. Besides, there is an extraordinary event of SHEQ Talks that is held annually, and the communicator is the line management which usually has ethos dimensions or factors, which is credibility, attraction, and power, that can influence the audience (Rakhmat, 20II). 
4......Tapi kalau soal SHEQ culture, di sini saya yakin pasti didengarkan atau diperhatikan secara baik. Tinggal pengemasan cara penyampainya saja, kalau terlalu kaku juga ga bagus. Kalo terlalu cair, nanti lebih banyak bercandanya. Walaupun komunikasi yang cair tetap jadi yang utama. Intinya disini harus balance, karena informasi mengenai pencegahan resiko kecelakaan kerja ga main-main. Ini menyangkut nyawa orang. (I am pretty sure workers are listening to the SHEQ talks and taking care of the SHEQ culture. How the communicator delivers the information is essential. It has to be not too strict or relaxed. Safety talk contains serious information but still have to be delivered in good communication)

(In-depth interview with one of Badak LNG workers)

The communicator of SHEQ talks has a significant role in the implementation of the program. They must touch the workers with empathy, which leads to safety behavior. Martin \& Bell (2009) suggested that a person can become a better communicator through empathy because they will be able to open the communicant's heart first. The communication pattern implemented by SHEQ talks communicators in disseminating live-saving rules occurred under a relaxed atmosphere. Although this is a formal program, the discussions appeared informal. Formal conditions are needed when the format carried is the big SHEQ talks because the number of audiences can reach hundreds of people from various departments.

Furthermore, the best way for companies to promote a safe work culture is by involving the workers in OSH management. SHEQ talks are also present in every informal activity as well as small groups within the company. SHEQ talks form small group communication, a two-way discussion between communicators and communicants numbering more than two people. The most effective communication concepts in exchanging messages are interpersonal communication and small group communication or face-to-face communication. The rest of the SHEQ talks always carry an informal theme regardless of the position or communication expertise in each department/division. Informal communication is essential to offer an exchange of knowledge and emotions when formal interaction is not possible. Sometimes, informal channels are more likely to communicate organizational culture (Grajewska, 20I7). Then, Badak LNG established a committee of OSH workers or management that aimed to solve OSH problems and model the relationship of behavior with accident risk factors (Hopkins, 1996).

Badak LNG employees have applied communication patterns to make the community in their company a SHEQ culture. SHEQ talks are practiced during the program precisely and during SHEQ moments, usually practiced during meetings, or discussions within the company environment. Perceptions of support from management and colleagues and trust in management and co-workers positively have made every employee who works in a company environment dare to voice safety issues at work (Burt et al., 2013).

SHEQ moments have become a particular habit that is always practiced by every Badak LNG employee. Therefore, it is not surprising that SHEQ talks, which are also part of the SHEQ moment, are something every employee needs as a result of the SHEQ culture that has taken root in the Badak LNG environment. From the researchers' findings and interviews with Mr. S, as an employee of the Fire and Safety Section at the Operation Department, it is increasingly emphasized that SHEQ talks have become a SHEQ culture that cannot be separated from work activities in the company environment.

“...SHEQ Talks udah jadi budaya di Badak. Terbukti setiap meetings, kita selalu menyempatkan waktu sejenak di awal pertemuan untuk membahas isu SHEQ culture lewat SHEQ moment yang ada unsur SHEQ Talks nya." (SHEQ talks have become a culture in Badak LNG. In every meeting, we always begin discussing SHEQ culture through SHEQ talks in every SHEQ moment.) (In-depth interview with one of Badak LNG workers) 
In the SHEQ moment, every employee will participate in applying SHEQ talks as a medium for conveying messages related to safety, health, or the environment. SHEQ moment includes the SHEQ talks program as a culture applied in the Badak LNG Company. All of this can happen because every employee has entered the interdependent stage. This stage allows the Badak LNG Company only to help its workers implement the SHEQ culture. Every employee has contributed to the SHEQ network and is proud of their SHEQ efforts all this time. The interdependent stage also changes the SHEQ talks program's culture, originally a mandatory program, into an activity that presents every moment of talks and meetings in the Badak LNG. This culture contributes to zero work accidents among workers.

\section{DISCUSSION}

Based on researchers' observations and secondary data, ${ }^{5}$ until now, the safety behavior of Badak LNG workers has reached an interdependent or cultured stage. At first, the SHEQ talks program's implementation was held because Badak LNG employees were obligated to implement the SHEQ MS (03-0) communication manual book. It had moved the safety behavior of Badak LNG employees from the reactive stage to the interdependent stage. The SHEQ culture has built the workers' habit to work safely to prevent the risk of work accidents. One of the tools that can help companies track their employee safety culture's evolution is the ${ }^{6}$ DuPont Bradley Curve, a tool for addressing occupational safety and health $(\mathrm{OSH})$ culture behavior in the workplace. From left to right, the image depicts a spectrum of safety culture from merely being reactive to being proactive.

This model characterizes the four stages of establishing a company's safety culture,

$5 \quad$ Badak LNG. (20I9). safety, health and environment, innovative, professionalism, integrity \& dignity "Kisah di Balik Ioo Juta Jam Kerja Aman Resep Jitu di Balik Ioo Juta Jam Kerja Aman." Majalah Badak LNG Edisi 4I.

6 DuPont. https://www.consultdss.com/bradleycurve/ Accessed at July, 3rd 2020, at I0.00 WIB. i.e., reactive, dependent, independent, and interdependent. In the early (reactive) phase, the company only relied on instincts to handle OSH without management commitment. Besides, the highest level was interdependent, making sure the company was actively involved in helping others carry out OSH activities. The interdependent stage has been able to transform each worker as "Guardians of Others." They have been able to take care of themselves (Kaczmarek et al., 2015).

The communicator of SHEQ talks always refers to the life-saving rules in SHEQ MS. ${ }^{7}$ Life-saving rules are nine general rules for working in the oil and gas industry. However, it is only used as a work accident prevention framework and not intended to replace the OSH company's management system. ${ }^{8}$ In this case, the life-saving rules that underlie the Badak LNG are: lack of permit to work, working at height, energy isolation, confined space entry, lifting operations, vehicle/equipment safety, excavation, and ground disturbances

According to Schramm in Effendy (2009)"communication will be successful if the message conveyed by the communicator (speaker) matches the frame of reference or the experience and understanding (collection of experiences and meanings) obtained by the communicant (listener)." If they meet each other in person, the communicators will immediately get responses or feedback from the communicants. The communicant can judge the logic of the communicator's description. Usually, the feedback can be given directly by asking questions to the communicator. It makes the SHEQ talks program the easiest step in delivering information about the risk of work accidents and even preventing environmental damage and health problems.

SHEQ talks are part of persuasive communication, with a multi-faceted domain of influence that can increase the communicator's

$7 \quad$ International Association Of Oil and Gas Procedure. 20I8. "Report IOGP Life-Saving Rules". Report : 459. publications@iogp.org.

8 Badak LNG SHE-Q MS. Tahun 2oII. Standard Operating Procedure (SOP) SHE-Q SHEQ Rules identification and implementation SHE-Q OI-II 5.O. 


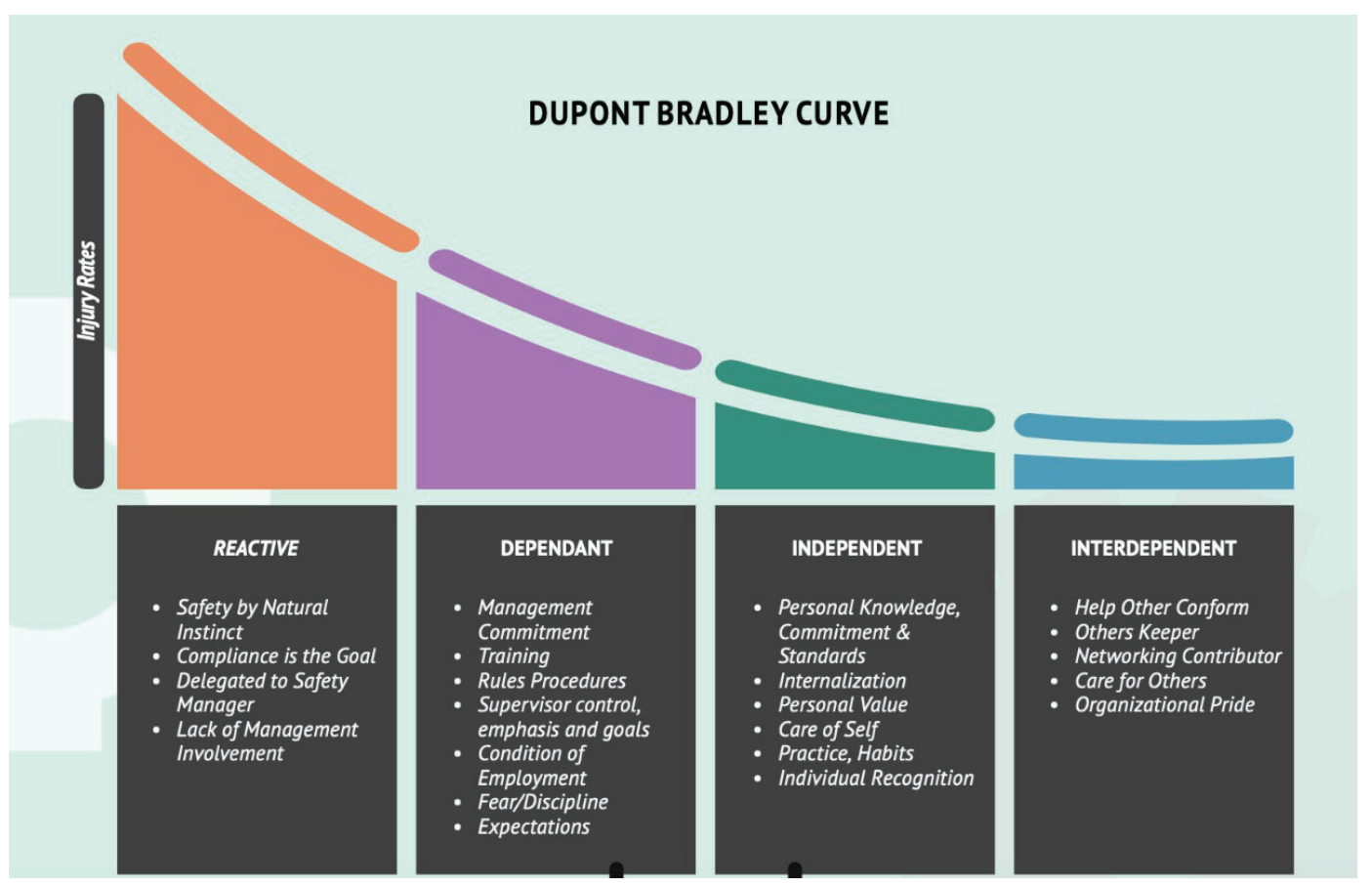

Figure I. Bradley Curves in Synergy Magazine (I2, 2019)

credibility and authority. These are useful skills to complement the essence of competitive and effective organizational communication (Ali et al., 20I2). Communication is dynamic, circular, and continuous. One of the basic human needs, as stated by Susanne K. Langer (in Mulyana, 2007), is the need to symbolize or use symbols. Humans are indeed the only animals that use symbols, and it distinguishes humans from other creatures. Ernst Cassier (in Mulyana, 2007) said that humans' superiority over other creatures is their specialty as animal symbolism.

Every action and interaction in the SHEQ Talks program is conducted with language, signs, and various symbols, leading to many kinds of interpretations and definitions according to each worker. The Symbolic Interaction Theory offered by George Herbert Mead describes that the human mind acts on objects differently based on the meaning they have. Then, the meaning arises from social interactions between social actors and is handled and modified through interpretation or self-concept (Mead in da Silva \& Vieira, 20II). This mind, self, and society concept proposed by George $\mathrm{H}$. Mead enables us to state that communication determines a person who knows his world and behaves.
Symbolic interaction refers to the characteristic of human interactions. It means that humans translate and define their actions in interactions with others and with themselves. It also involves using language symbols, provisions of customs, religions, and views (Mead in Ahmadi, 2008).

Various symbols about the risk of work accidents have been attached in every Badak LNG worker's mind. These symbols have been processed based on the distribution of reminder image symbols, along with Badak LNG employees' interactions in the SHEQ talks program (Ghani, 20I6). In every interaction, they always refer to the life-saving rules and SHEQS policies as a guide to avoiding the dangers lurking in the workplace. The workers usually interpret the guidelines together. Each worker can then equalize perceptions when discussing the SHEQ culture.

In the mind of each Badak LNG employee, various symbols about the risk of work accidents have been attached processed based on the distribution of reminder image symbols and interactions with fellow Badak LNG employees in the SHEQ talks program. Mead believes that symbols develop the mind and are used as tools 


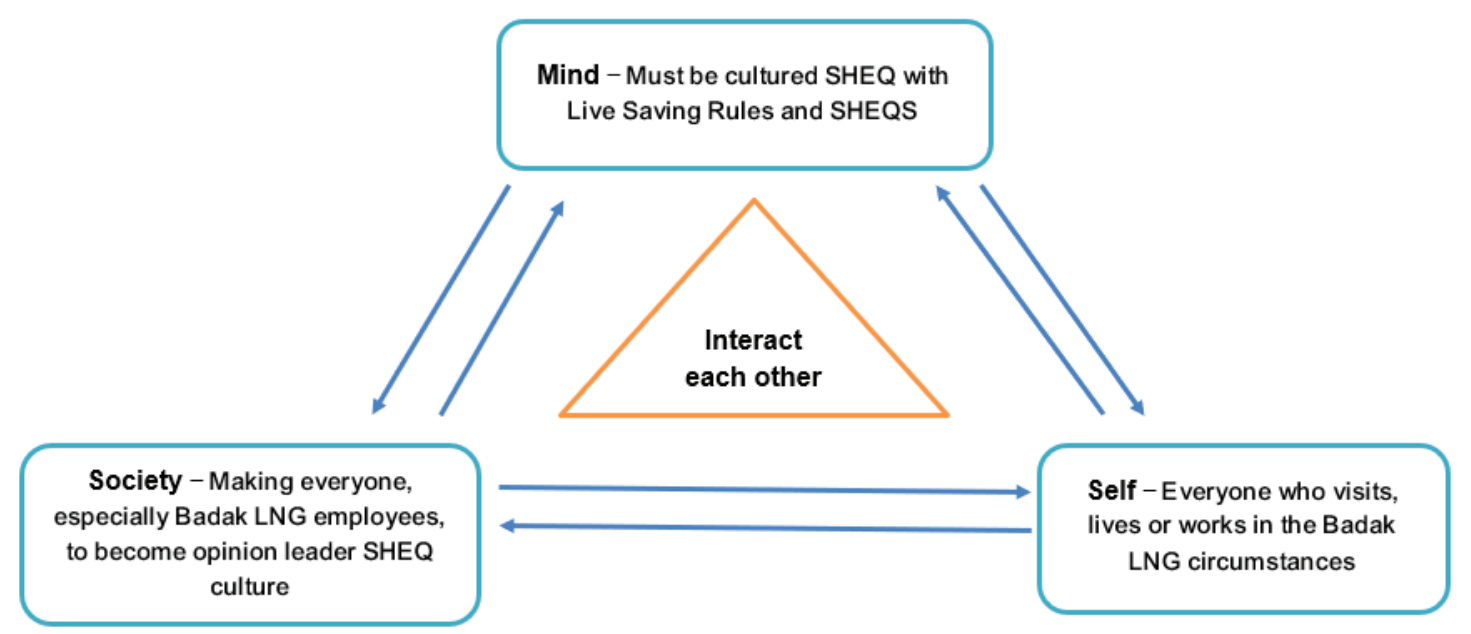

Figure 2. Communication Pattern Model to apply SHEQ Culture in the Badak LNG

for thinking and communicating to develop social products, namely interactions (Aksan et al., 2009) Human agents are reflexive, and shaped by social situations, which are interpreted in associational terms, as a complex network of interactions (Dennis \& Smith, 2015).

The principle of determining symbolic interaction argues that individuals (employees) or society, ontologically, can understand each other only by the relationship of interactions within their society (Snow, 20oI)wherein it has been referred to as one of the three major faces of social psychology (House I977. When the employees as a society in the same workplace have reached the same perception to prevent the risk of work accidents together, they have entered the interdependent stage. It is the stage where the workers knowingly and voluntarily help the company reduce work accidents to zero fatal accidents.

The SHEQ talks program will always remind workers of the risk prevention symbols by spreading it throughout the company. The symbols are in the manual books, posters, LCD slides, and SHEQ signs that have been scattered throughout the company. The selfunderstanding among the people who live, visit, and work in the Badak LNG is required to have a safety culture to prevent accidents. When they live as a society in the same workplace, they have reached the same perception to prevent work accidents. This condition is called the interdependent stage, where they knowingly and voluntarily work together to help the company reduce the number of work accidents to zero fatal accidents.

SHEQ talks are considerd unique, common in informing about risks and hazards in the workplace. SHEQ talks emphasize more the safety, environment, and health factors as a whole package that is equally important than the safety talk program, which only emphasizes safety as the main program. SHEQ talks present as a program that uses communication as a medium for interaction between fellow employees, subordinates, and subordinates who cut the command line and aim to change employees' behavior regardless of job differences.

SHEQ talks can be called as a communication program because it informs the whole SHEQ MS management system. Discussion is the main activity of SHEQ talks, making the workers aware of hazards in their workplace. This activity is conducted every day before the workers start their work to enable them to identify hazards that may arise during work. Moreover, the repeated information will stimulate the workers' subconscious on the importance of working safely (Somat, 2013). ${ }^{9}$ According to the Standard Operating Procedure (SOP) SHE-Q

$9 \quad$ PT Badak SHE-Q MS. Tahun 2ori. Standard Operating Procedure (SOP) SHE-Q SHEQ Rules identification and implementation SHE-Q OI-II 5.0. 
03-OI Communication of PT Badak LNG, SHEQ talks are formal meetings with departments or at least a working team. This activity is different from an office work-related activity, which also requires special preparation and must be followed by a special evaluation to prevent the risk of work accidents. Employees obtain to do this during regular meetings between employees, supervisors, managers, Senior Managers, and TOP Management to discuss Occupational Health and Safety issues.

To reduce the work accident rate, SHEQ MS must be understood, known, and applied by all the workplace workers. Accordingly, Badak LNG uses direct and fast communication between all workers to apply the SHEQ MS program. The good practice of safety communication should facilitate safety behavior and less injury in the workplace. The effect of communication about safety performance relationship could be applied through increasing the knowledge and information (Huang et al., 2018). Moreover, with communication, the information about safety procedures will be delivered to the workers. Communication is about delivering information related to an industry's general tasks according to Health and Safety at Work Law and specific regulatory requirements relating to a workplace (Huang et al., 2018).

SHEQ talk is a tool designed by the SHEQ-MS system that aims to exchange messages directly between employees in order to discuss how to prevent accidents and work safely. The SHEQ talks program can be a group communication for Badak LNG workers to remind each other of the importance of having a safe culture every time they are working. SHEQ- MS is a management system designed to implement procedures and policies in an organizational processes in a corporate organizational Badak LNG. The role of the management system in preventing the risk of work accidents is greatly important. The lack of policies and procedures is a common factor in the category of organizational processes which implies failure to provide sufficient resources for the company. The common factors identified in crew resource management include insufficient workforce, poor team communication, poor job planning and a lack of teamwork (Wold \& Laumann, 2015).

Therefore, SHEQ talk is a tool designed by the SHEQ-MS system that aims to exchange messages directly between employees to discuss how to prevent accidents and work safely. The SHEQ talks program can be a group communication for Badak LNG workers to remind each other of the importance of having a safe culture every time they are working. Communication is one of the most effective ways to change and maintain the interdependent stage safety behavior of Badak LNG workers. When conducting safety analysis, internal communication is preferred by the workers because it applies private discussion spaces that ensure correct understanding and timely feedback (Wang et al., 20I8). In communications like meetings or private discussions, tools such as SHEQ Talks can provide up-to-date information, such as implementing safety requirements. It is instrumental in daily work because workers can track safety progress, analyze it transparently, and provide timely feedback or comments (Wang et al., 2018).

\section{CONCLUSION}

Preventing fatal accidents in the oil and gas industries is a challenging matter to do. Many companies have already used the in-house version of the behavior-based safety approach to make the workers' health and safety performances more everlasting and do not entirely depend on OSH workers. Badak LNG, one of Indonesia's oil and gas industry, achieved zero accidents for several years by applying the SHEQ MS. Besides, the SHEQ talk program, as part of the SHEQ MS, becomes the critical activity to build the safety (or SHEQ) culture among Badak LNG employees. SHEQ talks program is delivered in the formal and informal situation, but much in the informal atmosphere.

The use of interpersonal communication in the SHEQ talks program has successfully delivered the OSH officer's safety knowledge to all the employees. This paper uses George Herbert Mead's theory of symbolic interaction, which consists of mind, self, and society. The SHEQ talks influence every worker's mind 
through social interaction, thus they can gain the right meaning of safety behavior. The excellent safety performance among Badak LNG employees has brought this company to the interdependent stage. This achievement is accomplished by getting through many stages before the interdependent. Focus on the transfer knowledge process and making safety knowledge an inclusive thing is a key for Badak LNG building the safety culture. Rather than focus on the outcome, the oil and gas industries should focus on the process of building a safety culture among their employees.

\section{REFERENCES}

Ahmadi, D. (2008). Interaksi Simbolik: Suatu Pengantar. Mediator: Jurnal Komunikasi, 9(2), 30I-3I6. https://doi.org/I0.293I3/mediator. v9i2.III5

Aksan, N., Kisac, B., Aydin, M., \& Demirbuken, S. (2009). Symbolic interaction theory. Procedia - Social and Behavioral Sciences, I(I), 902-904. https://doi.org/I0.IoI6/j.sbspro.2009.0I.I60

Ali, Z., Ho-Abdullah, I., \& Mastor, K. A. (20I2). Undergraduate Communication Style in Consensual Small Groups Decision Making. Procedia - Social and Behavioral Sciences, 59, 6I2-6I7. https://doi.org/I0.I0I6/j. sbspro.20I2.09.32I

Bernard, H. R. (Harvey R. (2006). Research methods in anthropology: qualitative and quantitative approaches. AltaMira Press.

Biezma, M. V., Andrés, M. A., Agudo, D., \& Briz, E. (2020). Most fatal oil \& gas pipeline accidents through history: A lessons learned approach. Engineering Failure Analysis, IIO. https://doi. org/ıo.ıoı6/j.engfailanal.2020.104446

Burt, C., Cottle, C., Näswall, K., \& Williams, S. (2013). Capturing Safety Knowledge: Using a Safety-Specific Exit Survey.

Castleberry, A., \& Nolen, A. (2018). Thematic analysis of qualitative research data: Is it as easy as it sounds? Currents in Pharmacy Teaching and Learning, Io(6), 807-815. https://doi. org/Io.Ioi6/j.cptl.2018.03.019

Creswell, J. W. (20I4). Penelitian Kualitatif dan Desain Riset. Pustaka Pelajar.

Creswell, J. W., \& Poth, C. N. (2017). Qualitative Inquiry and Research Design Choosing Among Five Approaches (Fourth). SAGE Publications, Inc. https://us.sagepub.com/en-us/nam/ qualitative-inquiry-and-research-design/ book246896\#contents

da Silva, F. C., \& Vieira, M. B. (20II). Books and canon building in sociology: The case of mind, self, and society. Journal of Classical Sociology, II(4), 356-377. https://doi. org/Io.II77/I468795XII4I5I48

Dennis, A., \& Smith, G. (2015). Interactionism, Symbolic. In International Encyclopedia of the Social \& Behavioral Sciences: Second Edition (pp. 352-356). Elsevier Inc. https://doi. org/Io.Ioi6/B978-0-08-097086-8.32079-7

Effendy, O. U. (2009). Komunikasi Teori dan Praktek. Remaja Rosdakarya.

Galis, A. A., Hashim, N., Ismail, F., \& Yusuwan, N. M. (20I8). The factors affecting Behaviour Based Safety (BBS) implementation in oil and gas industry. International Journal of Engineering and Technology(UAE), 7(3), 157-161. https:// doi.org/Io.I44I9/ijet.v7i3.II.I5952

Ghani, M. W. (20I6). Implementasi Program SHEQ Talks Dalam Upaya Pencegahan Resiko Kecelakaan Kerja Studi Kasus Implementasi Program SHEQ(SAFETY HEALTHENVIRONMENT QUALITY) TALKS Sebagai Upaya Pencegahan Resiko Kecelaka.

Grajewska, M. B. (20I7). Informal Communication. In The International Encyclopedia of Organizational Communication (pp. I-I5). Wiley. https://doi.org/Io.Ioo2/978III8955567. wbieocio8

Herdiansyah, H. (20II). Metodologi Penelitian Kualitatif untuk Ilmu-Ilmu Sosial. Salemba Humanika.

Hopkins, A. (I996). Making Safety Work: Getting Management Commitment to Occupational Health and Safety. Allen \& Unwin.

Huang, Y. hsiang, Sinclair, R. R., Lee, J., McFadden, A. C., Cheung, J. H., \& Murphy, L. A. (20I8). Does talking the talk matter? Effects of supervisor safety communication and safety climate on long-haul truckers' safety performance. Accident Analysis and Prevention, II7, 357-367. https://doi.org/Io.IoI6/j.aap.20I7.09.006

Iskandar. (200I9). Metodologi Penelitian Kualitatif. Gaung Persada.

Ismail, F., Hashim, A. E., Zuriea, W., Ismail, W., Kamarudin, H., \& Baharom, Z. A. (2012). Behaviour Based Approach for Quality and Safety Environment Improvement: Malaysian Experience in the Oil and Gas Industry. Procedia - Social and Behavioral Sciences, 35(December 20II), 586-594. https:// doi.org/Io.IoI6/j.sbspro.20I2.02.I25 
Kaczmarek, M. J., Szwedzka, K., \& Szczuka, M. (20I5). Behaviour Based Intervention for Occupational Safety - Case Study. Procedia Manufacturing, 3, 4876-4883. https://doi. org/Io.IoI6/j.promfg.20I5.07.6I5

Martin, P. G., \& Bell, K. K. (2009). "Open your heart first of all": perspectives of holistic providers in Costa Rica about communication in the provision of health care. Health Communication, 24(7), 63I-646. https://doi. org/Io.Io80/104I0230903242234

Mulyana, D. (2007). Pengantar Ilmu Komunikasi. Rosdakarya.

Rakhmat, J. (20II). Psikologi Komunikasi. Rosdakarya.

Salam, A. A. A., Al Qallaf, Y., Pichery, L. A., \& Adivi, B. S. S. (2013). Implementing Behavior Based Safety (BBS) program in a middle eastern work environment: Lessons learned. Society of Petroleum Engineers - SPE Americas E and $P$ Health, Safety, Security, and Environmental Conference 20I3, 225-233. https://doi. org/ıo.2118/16376I-ms

Septalita, E. D. (2018). Kecelakaan Kerja Di Area Pengeboran Minyak Dan Gas Tahun 2012 - 2016. The Indonesian Journal of Occupational Safety and Health, 7(I), 52. https://doi. org/ı0.20473/ijosh.v7ir.2018.52-62

Snow, D. A. (200I). Interactionism: Symbolic. In International Encyclopedia of the Social \& Behavioral Sciences (pp. 7695-7698). Elsevier. https://doi. org/10.10i6/bo-08-043076-7/01905-7

Somat, I. (2013). Teknik Efektif Dalam Membudayakan Keselamatan dan Kesehatan Kerja. Pt Dian Rakyat.
Theophilus, S. C., Esenowo, V. N., Arewa, A. O., Ifelebuegu, A. O., Nnadi, E. O., \& Mbanaso, F. U. (20I7). Human factors analysis and classification system for the oil and gas industry (HFACS-OGI). Reliability Engineering and System Safety, I67, I68-I76. https://doi. org/10.10I6/j.ress.2017.05.036

Wang, Y., Graziotin, D., Kriso, S., \& Wagner, S. (2018). Communication channels in safety analysis: An industrial exploratory case study. https://doi. org/Io.IoI6/j.jss.20I9.04.004

Wold, T., \& Laumann, K. (2015). Safety Management Systems as communication in an oil and gas producing company. Safety Science, 72, 23-30. https://doi.org/ıo.Ioi6/j.ssci.2014.08.004

Zhang, Y., Shao, W., Zhang, M., Li, H., Yin, S., \& Xu, Y. (20I6). Analysis 320 coal mine accidents using structural equation modeling with unsafe conditions of the rules and regulations as exogenous variables. Accident Analysis and Prevention, 92, 189-201. https://doi. org/ıo.Ioi6/j.aap.2016.02.02I

Zigulis, G. (20I5). Behavior based safety programs Should they be implemented? Occupational Health and Safety, October. 
